\title{
Criminal Law Protection Of Indonesian Citizens Whose Name Is Used Nominally By Foreigners
}

\author{
Simon Nahak \\ \{info@warmadewa.ac.id\} \\ Universitas Warmadewa, Bali-Denpasar
}

\begin{abstract}
The control of land rights by foreign countries has no definite arrangement, but in its implementation, many foreign nationals control the land through nominee agreements. Therefore, the aims of the study are to describe the legal protection which given to Indonesian citizens (foreign citizens) nominally by foreigners and the consequences of criminal law arising for foreigners who use Foreign Citizens (Indonesian Citizens) for land ownership. This study uses normative research methods, which is the existence of empty norms in the control of land rights by foreigners. The approach used were statutory approach and Conceptual approach. Criminal law protection granted to Indonesian citizens (foreign nationals) nominally by a Foreigner that is direct legal action that can transfer ownership rights to land to foreigners including sale and purchase, exchange, Rental Rights, and Right to Use. Because Foreign Citizens cannot be subject to Property Rights, with more open opportunities for Foreign Citizens to live in Indonesia due to their duties/jobs and other indirect legal actions can be categorized as acts of legal smuggling including; Master Agreement consisting of Land Ownership Agreement (Land Agreement) and Power of Attorney; Option Agreement; Lease Agreement; Testament Grants; Statement of Heirs. Criminal consequences arising for foreigners who use Foreign Citizens Nominees (Indonesian Citizens) for land ownership, if reviewed from the making of deeds made by Notaries and parties, there is a criminal act of falsifying a letter made by Indonesian Citizens originating from the Agreement Nominees, falsification of authentic certificates violates Article 263 of the Criminal Code; Article 264 of the Criminal Code.
\end{abstract}

Keywords: Criminal; Foreign nationals; Nominee; Protection

\section{Introduction}

Nowadays there are many foreigners living in Indonesia who have land rights, especially Bali as a tourist destination is inseparable from foreigners' control of land rights because Bali is an area that has many attractions, including cultural arts diverse and beautiful beaches scattered there. This makes Bali a very popular tourist area, which is visited by many local and foreign tourists. In subsequent developments, many foreign tourists are interested in buying land and owning it with ownership rights in the area, both to establish residential homes and for investment. However, this is not possible. National land law prohibits foreign nationals 
from owning land with Proprietary Rights in Indonesian territory. The national land law stipulates that only Indonesian citizens are entitled to own land with Proprietary Rights in Indonesian territory. Considering this, a Nominee agreement was made between Foreign Citizens and Indonesian Citizens. By using the Nominee agreement, Foreign Citizens can own land with Proprietary Rights in Bali by registering the land in the name of an Indonesian citizen who is designated as Nominee.

The occurrence of borrowing names by Foreign Citizens to Indonesian Citizens as a form of violation of the law, which is carrying out legal smuggling, because Foreign Citizens have no right to control land as ownership rights, Foreign Citizens can only control land such as Building Use Rights; and Right to Use.

The occurrence of legal smuggling by Foreign Citizens to Indonesian Citizens that is by borrowing the name of the Indonesian People and the Notary's role in making Nominee agreements, while in Normative law the use of Nominee agreements is not permitted in the legal system in Indonesia.

The control of land rights by foreigners using the Nominee agreement occurs in tourist areas such as Nusa Dua; Kuta; Jimbaran and Ubud, Notaries/Conveyancer as officials who make authentic deeds have violated the Notary Ethics Code, if a dispute occurs in the Notary Nominee agreement, the legal liability can be held.

The realization of this Nominee is in the agreement letter made by the parties, that is between the Foreign Citizen as the authorizer and the Indonesian citizen as the authorizer (Nominee) created through a single package of agreements that basically intends to give all authority that might arise in the relationship the law between a person and his land to a Foreign Citizen as the recipient of the power of attorney to act like a true owner of a piece of land that according to the law cannot be owned ( $H M$ or $H G B$ ). An agreement using such power, using the Indonesian citizen as a Nominee is legal smuggling because its substance is in conflict with the Basic Agrarian Law [1].

Foreign nationals who carry out legal actions in Indonesia will still be protected by law because the Indonesian is a state of law. In his life, foreign citizens may have bad intentions (tekwaadetrouw) with a specific purpose or goal. This objective is to rule out the enactment of national legal provisions in ways that are not justified [2].

The latest related studies have been conducted previously. Takariawan \& Putri (2018) carried out the study about legal protection on human trafficking victims in the human rights perspective. The study revealed that the legal protection for trafficking victims are in the forms of restitution, compensation, and rehabilitation, while some other forms of legal protection are not applicable due to various factors. Article 48 in Law No.21 of 2007 concerning Human Trafficking is not applicable so that either the article needs amendment or its implementing regulation is made, so that the rights of victims in the trial can be implemented. Another latest related research was about legal protection for internet users against web contents with clickbait on online media. The result showed that there are no laws and regulations that specifically regulate this clickbait. Besides that, the methods used to reduce the articles with click bait include education, improvement of community literacy, learning about the critical news consumption, or can be pursued through legal proceedings both under the civil or penal codes (Kusumawardani, 2019). This present study tried to describe the legal protection which given to Indonesian citizens (foreign citizens) nominally by foreigners and the consequences of criminal law arising for foreigners who use Foreign Citizens (Indonesian Citizens) for land ownership. 


\section{Methods}

This type of research was Normative Law research (doctrinal research). The approach used were statutory approach (Statue approach) carried out by examining all laws and regulations relating to the legal issues being addressed and Conceptual approach carried out by examining cases related to the issues faced that have become court decisions that have permanent legal force. This research was carried out by examining the primary legal materials and secondary legal materials, a research using materials that are not derived from observations or interviews but on non-human sources that are document [3]. Its purpose is to obtain normative clarity of the problem under study as well as the results obtained in connection with the status of foreign citizen status in the Nominee agreement made by a notary. The collection of legal materials are carried out by inventorying, studying and exploring primary and secondary legal materials related to research by making notes on a small card and classifying these materials. Systematization needs to be done horizontally by tackling the numbering or formulation of the legislation in this case, the Civil Code and related issues [4]. Analysis can be formulated as a process of decomposition in a systematic and consistent manner against certain symptoms. A systematic breakdown of the symptoms or data obtained in this study is then analyzed quantitatively. Then identify from the data collected from primary and secondary material and is done with the argumentation technique and systematization technique. Argumentation technique is an assessment that is based on reasons that are legal deepening reasoning. With this systematic technique that is by looking for the relationship of a legal norm between the laws and regulations studied. However, the results of the analysis are expected to be able to obtain results or conclusions on the issues raised, especially those related to the issues raised.

\section{Results And Discussion}

\subsection{Criminal Law Protection Given to Indonesian Citizen (Foreign Citizen) Nominally by Foreigners}

The occurrence of nominee agreements made by Foreign Citizens to Indonesian Citizens often occurs this is because there are no definite rules governing the control of land rights by foreigners in Indonesia.

The control of land rights by foreigners in Indonesia by using a nominee agreement, which is borrowing names to Indonesians to conduct transactions, however, it is not uncommon for nominees to use for disputes between Foreign Citizens and Indonesian Citizens, so that the injured party is a Foreign Citizen, because in the nominee agreement stated in the name of an Indonesian citizen. The use of nominees as a form of violation of the law is the occurrence of legal smuggling. Legal actions that directly transfer ownership rights to foreigners are done intentionally such as selling, granting, exchanging, bequeathing a will is clearly prohibited by law, Article 21 paragraph (1) jo Article 26 paragraph (2) agrarian basic law. But the transfer of property rights to foreigner happened accidentally, for example: because of inheritance without a will, because of the mixture of assets due to marriage, and because of loss of Indonesian citizenship, is not contrary to the law.

Foreigners Control land rights through direct legal action for Foreign Citizens in controlling land rights through sale and purchase; exchange; gifting; giving a will. Whereas indirect legal actions of transferring land rights to Foreign Citizens can be carried out with the Nominee agreement. Besides that the land which was used as the object of making the deeds 
had legally fallen into state land. Based on Article 1 paragraph 1 of law of notary position, it showed that the authority of a notary is to make an authentic deed.

The notary is given authority by law in making an authentic certificate, but it is not given the authority to make a Nominee agreement, because the Nominee agreement is as legal smuggling that has not been regulated in the law. Notary in making a deed does not merely pour the wishes of the parties but must be analyzed first so that the making of the deed does not violate or contravene the applicable laws and regulations. Do not let the existence of the deed made by the Notary may cause disputes between the parties, or it can disturb public order. The legal product in the form of an authentic deed produced by a notary must be of high quality so that the notary who makes it can be valued by the public as a professional notary.

If you pay attention to the legal construction of the making of these deeds, it can be concluded that the making of the deeds meant is to provide legal protection which is deemed sufficient and in the best interests of the foreigners in controlling land rights. If the legal construction of the name lending by making a deed of Statement and is equipped with a Power of Attorney to Sell and the Binding of the Purchase Agreement, turns out to be a legal problem or is cancelled based on the law, then there is still another bond in the form of accounts payable debts based on the Deed Acknowledgment and the imposition of collateral in the form of land with the Deed of Granting Mortgage Rights. Juridical safeguards carried out in layers also indicate that there is doubt about the strength of the law possessed if only one legal construction is made. According to researchers can pose even greater risks in the future.

The deed making at the same time shows that from the beginning there had been an attempt to carry out legal smuggling of control of land rights by foreigners. From the beginning of the purchase, it was done by disguising (using a mask), that is by borrowing or using the name of an Indonesian citizen, and then made a name loan deed and also made a sale and purchase agreement to foreigners (foreigners) and authorization to foreigners to sell/transfer rights to children. By using the deed/Power of Attorney, then the Deed of Confession of Credit and the imposition of the guarantee shall be made by making the deed of Granting Mortgage Rights. From the series of the drafting of these deeds according to the researchers shows that there is an attempt of legal smuggling by using authentic deeds as mentioned above. The ultimate goal is for foreigners to take control of the land and take all actions that can be carried out as befits an owner. Whereas for the purpose of ownership by foreigners, it has been clearly prohibited by the laws and regulations in force in Indonesia as mentioned in Article 26 paragraph (2) agrarian basic law. Based on the interview results of researchers with 5 Notaries/Conveyancer in Tabanan Regency - Bali, it can be seen that the notary public still maintains the opinion that the notary as a public official in accordance with current practice, is only obliged to record what is formally submitted by the parties or in words others a notary does not need to know the material truth of the things raised by the parties. Yet if it is noted that an authentic deed has perfect proof power, then this can no longer be justified.

\subsection{The consequences of criminal law arise for foreigners who use Nominee Foreign Citizens (Indonesian Citizens) for land ownership}

The legal consequences that occur against foreigners in controlling land rights when examined from the making of a deed made by a Notary and the parties, the criminal act of forgery of a letter occurs, we can find the provisions in Article 263 of the Criminal Code which explains:

1. Anyone who makes a fake letter or falsifies a letter that can cause a right, a bond or a debtfree, or is intended as evidence of something with the intention to use or order others to use 
the letter as if the contents are correct and not forged, threatened if used This can result in losses, due to falsification of the letter, with a maximum imprisonment of six years.

2. Threatened with the same crime, whoever intentionally uses fake or forged documents as if true, if the use of the letter can cause harm.

Furthermore, Article 264 of the Indonesian Criminal Code states that:

1) The falsification of the letter is punishable by imprisonment for a maximum of eight years if it is carried out against:

a) authentic deeds;

b) debt securities or debt certificates from a country or part of it or from a public institution;

c) sero letter or debt or sero certificate or debt from an association, foundation, company or airline

d) proof of dividend or interest from one of the letters described in 2 and 3, or proof issued in lieu of the documents;

e) letters of credit or commercial letters intended for distribution;

2) Threatened with the same criminal who intentionally uses the letter in the first paragraph, the contents of which are not true or falsified as if true and not forged, if the falsification of the letter can cause harm.

The Criminal Code and its Comments Complete Article by Article (p. 195) says that what is meant by the letters in this chapter are all letters, whether written by hand, printed, or written using a typewriter, and other things. The falsified letter must be a letter which:

1) can emerge to a right (for example diplomas, entrance tickets, share certificates, etc.);

2) can issue an agreement (for example a receivable agreement, sale and purchase agreement, rental agreement, etc.);

3) can issue a debt relief (receipt or similar letter); or

4) a letter used as a description of an act or event (for example a birth certificate, postal savings book, cash book, diary of ships, transportation letters, bonds, etc.) The forms of forgery of the letter according to Soesilo are carried out by:

a. making fake letters: making content is not appropriate (incorrect).

b. faking letters: changing letters so that their contents are different from the original contents. The method varies, the letter is not always replaced with another one, it can also be subtracted, added or changed something from the letter.

c. faking signatures also includes the notion of faking letters.

d. attaching photos of other people from eligible holders (for example photos in a school diploma).

Law of Notary Position and Notary Professional Code of Ethics which can plunge a notary public leads to an authentic falsification of a letter/deed. In connection with Normative Juridical Analysis of Falsification of Authentic Deed Conducted by a Notary Public, then based on the Formulation of the Elements of Criminal Acts against Falsifying Authentic Deed conducted by a Notary Public is about the Article 263 of the Criminal Code concerning falsification of letters in general cannot be applied to the offender, that is the Notary who falsified the Authentic Deed. However, the notary may be subject to sanctions from Article 264 paragraph (1) and (2) (Criminal Code) because article 264 of the Criminal Code is a falsification of a letter that is aggravated because the object of the forgery contains a high value of trust [5].

While the article 266 of the Criminal Code can be applied to the offender who ordered the notary to make a deed with false information because legally commits a criminal offense and the Legal Consequences of Falsification of Authentic Deed conducted by a notary, that is, the 
victim/victim suffers a loss on the making of a deed containing false information by a notary. False deeds that have been made can be cancelled. So regarding the cancellation of the deed is the authority of the civil judge, namely by filing a civil suit in court. And according to the Law of Notary Position may be subject to Administrative Sanction/Violation of the Notary Professional Code of Ethics in the form of oral, written reprimands to the dishonourable discharge from the Supervisory Board. and Civil Sanction article 1365 of the Civil Code regarding compensation.

The legal consequences of foreigners as legal smuggling, the term legal smuggling is the equivalent of the term Westonduiking (Dutch); Fraunde a la loi (France); Fraus Legis (Latin); Gesetzesumgehung, das Hadeln in Fraudem Legis (Germany); Fraudulent Creation of Contract (English); and Frode alla Legge (Italy) [6]. Whereas public order is the equivalent of the terms Public Ordre (French), Openbare order (Dutch), Public Policy, Public Order (English). Hegal argues that the concept of "Public Order" is basically about an untouchable part of the local legal system, therefore foreign law (which should apply) can be ruled, if it is deemed to be contrary to the "untouchable part" of the lex fori.

The example of Gianyar District Court Decision Number 41/Pid.B/2018/PN.Gin, dated June 26, 2018, the falsification of an authentic certificate by defendant I Wayan SUdarsana alias Darsa, 40 years; the address of Banjar Kerta, Kerta Village, Payangan Subdistrict, Gianyar Regency, that in the prosecutor's claim the Defendant legally and was convinced of falsifying a deed at the Notary Office of Ni Nyoman Ayuni, SH., M.Kn, Jalan Andong Gianyar, by ordering false information to be entered into a deed concerning something whose truth must be stated by the deed, with the intention to use or order someone else to use the deed if the statement is in accordance with the truth, if because of the use it can cause losses in accordance with article 266 of the Criminal Code. By stating evidence 1 join ate copy of agreement No. 01 March 23, 2017; 1 (one) receipt on March 23, 2017, Rp. 935,064,000 and March 23, 2017 Rp. 47,952,000.

The Judge of Gianyar District Court has examined and decided that the criminal act of forgery in accordance with the Prosecutor's claim violated article 266 paragraph (1) and both Article 378 of the Criminal Code by deciding it was not legally proven and convincing to commit a criminal act, because the defendant's actions were known by the victim-witness, so the accused was acquitted and rehabilitated. The Public Prosecutor of Gianyar District Court made an Appeals and Appeal of the Denpasar High Court rejected the verdict of the District Court and Gianyar and the Court of Justice itself has examined and decided that the Defendant was legally convicted of falsifying criminal acts in violation of article 266 paragraph (1) of the Criminal Code and the second article 378 of the Criminal Code. Because it meets the elements; Whoever; with the intent to benefit oneself or others by unlawful acts, by using false names or false dignity, by deception, or by a series of lies, moving others to hand over something to him or to give debt or write off debt.

\section{Conclusion}

The conclusion that can be made based on the result above are:

1. Criminal legal protection granted nominally to citizens by foreigners, that is direct legal actions that can transfer ownership rights to land to foreigners include; sale and purchase; exchange; Lease Right, and Right to Use. Because Foreign Citizens cannot be subject to Property Rights, with the opening of opportunities for Foreign Citizens to live in Indonesia in connection with their duties/work and other indirect legal actions can be 
categorized as acts of smuggling of law including; Main Agreement consisting of Land Ownership Agreement (land Agreement) and Power of Attorney; Option Agreement; Lease Agreement; Probate Grant; Declaration of Heirs.

2. As a result of criminal law that arises for foreigners who use the Nominee of Foreign Citizens (Indonesian Citizens) for land ownership, if reviewed from the making of a deed made by a Notary and the parties, the criminal act of falsification of a letter made by an Indonesian citizen originating from Nominee Agreement, falsification of authentic deeds violates Article 263 of the Criminal Code; Article 264 of the Criminal Code. As for the forms of falsification of the letter, according to Soesilo, it was carried out by providing false statements in the making of a notary deed as if making a truth about the event, the notary in the issuance of an authentic deed also violates the Law of Notary Position, while foreigners violate the law smuggling carried out with the goal is to avoid certain conditions or consequences that are desired or to realize or create a desired legal effect. In Gianyar District Court Decision Number 41/Pid.B/2018/PN.Gin, dated June 26, 2018, the falsification of authentic deed by defendant I Wayan SUdarsana alias Darsa, 40 years; not proven to have committed an authentic act of forgery not proven to be legally and convincingly, but the Court of Appeal stated that he was proven guilty and convincingly committed the falsification of an authentic deed.

\section{References}

[1] M. S. Sumardjono, "Alternative Policies on Regulation of Land Rights and Buildings for Foreign Citizens and Foreign Legal Entities," Kompas, Jakarta, 2007.

[2] B. Mustafa, Agrarian Law in Perspective. Bandung: Remadja Karya, 1985.

[3] Nasution, Qualitative Naturalistic Writing Method. Bandung: Tarsito, 1998.

[4] S. Soekanto and Srimamuji, Normative Legal Research (A Brief Review). Jakarta: PT. Raja Grafindo Persada, 1985.

[5] L. I. Nasution, Evaluation of the Implementation of the LoGA for 38 Years and Current and Future Programs in Facing Globalization. 2002.

[6] J. Braithwaite, Restorative Justice \& Responsive Regulation. Newyork: Oxford University Press, 2002. 